\title{
FILOLOGI \\ (Sebuah Pendekatan Mengkaji Kitab Keagamaan)
}

\author{
H. M. Arsyad Almakki*
}

\begin{abstract}
Abstrak
Teks keagamaan dalam bentuk kitab atau buku - dalam berjalannya waktu - banyak yang tidak dipelihara dengan cermat, Akibatnya mengalami banyak kerusakan. Sehingga untuk membaca dan memahami teks keagamaan tersebut mengalami kendala cukup besar. Filologi merupakan salah satu pendekatan dalam studi keislaman (Islamic Studies). Pendekatan yang bisa digunakan untuk mengkaji teks atau kitab-kitab keagamaan (fiqh, tafsir, tasawuf). Filologi dalam dalam dunia Islam di kenal dengan Tahqiq. Filologi digunakan untuk mengkaji teks atau kitab-kitab keagamaan yang telah banyak rusak dimakan waktu atau korup serta memurnikan teks dengan mengadakan kritik sehingga menghasilkan suatu teks yang paling mendekati aslinya.
\end{abstract}

Kata Kunci: Teks keagamaan, Filologi, objek filologi, metode filologi

\section{A. Pendahuluan}

Agama merupakan sesuatu yang berhubungan dengan keyakinan, keimanan dan kepercayaan seseorang. Agama- dalam pembahasan ini -tidak dipandang dan diteliti secara sepihak atau memandang agamanya lebih baik dan menghina agama lain. Akan tetapi, pemahaman agama dipandang secara objektif mengenai kebenarannya dengan sikap yang relatif. Sehingga, hal itu diperlukan beberapa pandangan atau pendapat dari beberapa ilmuwan.

Agama memang tidak dapat dipisahkan dari aspek bahasa, karena manusia adalahmakhluk berbahasa sedangkan doktrin agama dipahami, dihayati dan disosialisasikan melalui bahasa. Melalui bahasa manusia dan makhluk-makhluk lain dapat berkomunikasi.

Islam lahir sebagai gejala lisan dan praktek tanpa tulisan, tetapi

* Penulis adalah Dosen STAI RAKHA Amuntai dan Alumni Pascasarjana (S2) Hukum Islam Universitas Islam Negeri Sunan Kalijaga Yogyakarta.

Jurnal Ilmiah Al QALAM, Vol. 11, No. 23, Januari-Juni 2017 
tidak lama kemudian terbentuk teks-teks tertulis yang menjadi sandaran utama di dalam perumusan ajaran. Sebenarnya di dalam kedua hal itu peran bahasa sangatlah besar dan ini disadari oleh para pemikirperumus ajaran Islam, sebagaimana terbukti dalam banyaknya kajian tentang bahasa arab yang dilahirkan oleh para ulama. Gramatika dan morfologi Arab (al-nahw wa-l-sharf) termasuk dalam ilmu yang mulamula dikembangkan. ${ }^{1}$

Filologi adalah sebuah kajian tentang teks suatu bahasa.Filologi merupakan salah satu pendekatan yang ada dalam studi Islam (Islamic Studies).Studi Islam secara harfiah adalah kajian tentang hal-hal yang berkaitan dengan keislaman.

Dalam Islamic Studies, filologi sering digunakan untuk mengkaji al-Qur'an, al-Hadits maupun naskah-naskah keislaman lainnya. Karena kesemuanya itu menggunakan bahasa tersendiri sebagai mediumnya.Tentu saja, setiap bahasa mengandung ciri-ciri kesusastraan yang memerlukan penelitian kesastraandi dalam memahaminya dengan baik.

\section{B. Pembahasan}

1. Pengertian

Filologi secara bahasa berasal dari kata Yunani "philos" yang berarti "cinta" dan "logos" diartikan "kata". Pada kata filologi ke dua kata itu membentuk arti "cinta kata" atau "senang bertutur".Arti ini kemudian berkembang menjadi "senang belajar"

${ }^{1}$ Machasin, "Penelitian Bahasa dan Sastra Dalam Kajian Keislaman" dalam Ahmad Pattiroy (ed.), Filsafat dan Bahasa Dalam Studi Islam, (Yogyakarta: Lembaga Penelitian UIN Sunan Kalijaga, 2006), hal. 77.

Jurnal Ilmiah Al QALAM, Vol. 11, No. 23, Januari-Juni 2017 
atau "senang kebudayaan". 2

Sejak sekitar abad ke-3 S.M. istilah filologi sudah dipakai oleh para ahli di Aleksandria. Dikatakan bahwa kegiatan mereka adalah berusaha mengkaji teks-teks lama yang berasal dari bahasa Yunani.Pengkajian mereka terhadap teks-teks tersebut bertujuan menemukan bentuknya yang asli untuk mengetahui maksud pengarangnya dengan jalan menyisihkan kesalahan-kesalahan yang terdapat di dalamnya. Usaha mencari perbedaan bacaan yang terdapat di dalam teks (varian) akan diketahui adanya bacaan yang rusak (Korup). ${ }^{3}$

Di Negara Belanda, istilah filologi berarti perangkat pengetahuan yang berhubungan dengan studi teks sastra atau budaya dikaitkan dengan latar belakang dengan kebudayaan yang didukung oleh teks tersebut. Lain lagi di Prancis, filologi selain mendapat arti studi bahasa melalui dokumen tertulis, ia juga merupakan studi tentang isi teks lama dan transmisinya. ${ }^{4}$

Jadi, tugas filologi adalah untuk memurnikan teks ${ }^{5}$ dengan mengadakan kritik terhadap teks, dan tujuan kritik teks ialah menghasilkan suatu teks yang paling mendekati aslinya. Teks yang sudah dibersihkan dari kesalahan-kesalahan dan telah tersusun

${ }^{2}$ Nabilah Lubis, Naskah, Teks dan Metode Penelitian Filologi, (Jakarta: Forum Kajian Bahasa dan Sastra Arab Fak. Adab IAIN Syarif Hidayatullah, 1996), hal. 15.

${ }^{3}$ Siti Baroroh Lubis, yang dikutip Istadiyantha,Edisi Teks dan Ruang Lingkup Pengembangan Penelitian Filologi, https://www.scribd.com/, di akses 26 Desember 2012.

${ }^{4}$ Nabilah Lubis, Naskah, Teks dan Metode Penelitian Filologi..., hal. 21.

${ }^{5}$ Yang dimaksud dengan teks adalah kandungan atau isi naskah. Perbedaan antara naskah dan teks akan menjadi lebih jelas jika terdapat naskah yang lebih muda tetapi mengandung teks yang lebih tua. Teks sendiri terdiri dari isi dan bentuk.Isi mengandung ide-ide, atau amanat yang ingin disampaikan oleh pengarang kepada pembaca.

Jurnal Ilmiah Al QALAM, Vol. 11, No. 23, Januari-Juni 2017 
H.M. Arsyad Almakki: Filologi (Sebuah Pendekatan Mengkaji Kitab Keagamaan)

kembali seperti semula merupakan teks yang dapat dipertanggungjawabkan sebagai sumber untuk kepentingan berbagai penelitian dalam bidang-bidang ilmu lain. ${ }^{6}$

Sedangkan dalam ilmu keislaman, filologi dikenal dengan istilah tahqiq.Secara bahasa, tahqiq berarti tashhih (membenarkan) dan ihkam (meluruskan).Sedangkan secara istilah berarti menjadikan teks yang ditahqiq sesuai dengan harapan pengarangnya baik bahasanya maupun maknanya. ${ }^{7}$

2. Objek Filologi

Dalam penelitian filologi, yang menjadi objeknya adalah peninggalan tulisan masa lampau yang kita kenal dengan kata-kata "naskah" kata Arab, "manuskrip" kata latin, dan "kodeks" yang berarti tulisan tangan. Di Indonesia istilah yang digunakan adalah "naskah". Kandungan yang tersimpan dalam naskah, dalam kegiatan filologi, pada umumnya disebut teks. ${ }^{8}$

Berbeda dengan produk masa kini, hasil cipta masa lampau pada saat ini berada dalam kondisi yang tidak selalu dapat diterima dengan jelas dan sering dikatakan "gelap" atau "tidak jelas" oleh pembaca masa sekarang. Sebagai akibatnya banyak karya tulisan masa lampau dirasakan tidak mudah dipahami.

${ }^{6}$ Siti Baroroh Lubis, yang dikutip Istadiyantha,Edisi Teks dan Ruang Lingkup Pengembangan Penelitian Filologi, https://www.scribd.com/, di akses 26 Desember 2012

${ }^{7}$ Habib Kamil, "Tahkik Al-Kutub: Menyoal Peran Perguruan Tinggi Dalam Menyelamatkan Orisinalitas Intelektual Bangsa" pada Seminar Regional Studi Manuskrif Dalan Khazanah Qur'anic and Hadith Studiesdi UIN Sunan Kalijaga Yogyakarta, 16 Desember 2008, hal. 1.

${ }^{8}$ Kun Zachrun Istanti, "Studi Manuskrip dan Muatannya” pada Seminar Regional Studi Manuskrif Dalan Khazanah Qur'anic and Hadith Studiesdi UIN Sunan Kalijaga Yogyakarta, 16 Desember 2008, h. 3. Lihat pula Nabilah Lubis, Naskah, Teks dan Metode Penelitian Filologi, .. hal. 22.

Jurnal Ilmiah Al QALAM, Vol. 11, No. 23, Januari-Juni 2017 
Pada dasarnya menurut filologi teks yang disalin senantiasa mengalami perubahan atau tidak setia dalam penurunannya baik karena tidak sengaja (misalnya keterbatasan dan subjektivitas, kesalahan, keteledoran penyalinnya) maupun karena disengaja (misalnya untuk menciptakan hal yang baru pangsa pembaca). ${ }^{9} \mathrm{Hal}$ ini menimbulkan variasi-variasi dalam hasil penurunannya dan juga menimbulkan sikap terhadap variasi itu.

3. Tujuan dan Kegunaan Filologi

Sebagian filologi berpendapat, tujuan penelitian tidak hanya sebatas pada teks sebagaimana adanya dalam naskah tetapi juga menyajikan teks yang baik dan sesuai dengan kriteria ilmiah, termasuk membuat batasan-batasan, pembagian alinea, memberi penjelasan, dan memperbaiki kesalahan-kesalahan yang dianggap perlu.Metode yang biasa digunakan dalam tahqiq atau editing naskah Arab lama mewajibkan penyebutan teks sebagaimana adanya, kemudian perbaikannya disebut dalam catatan kaki.

Menurut Baroroh Baried, secara rinci dapat dikatakan bahwa filologi mempunyai tujuan umum dan tujuan khusus. ${ }^{10}$

a. Tujuan Umum

1) Memahami sejauh mana perkembangan suatu bangsa melalui sastranya, baik tulisan maupun lisan,

2) Memahami makna dan fungsi teks bagi masyarakat

${ }^{9}$ Menurut Martin L. West, sebagaimana dikutip Nabilah Lubis, mengingatkan bahwa sebab-sebab terjadinya kesalahan itu cukup banyak, antara lain; penyalin kurang memahami bahasa atau pokok persoalan naskah yang disalin, mungkin pula karena tulisannya kurang jelas (kabur/buram), karena kesalahan pembacanya atau disebabkan oleh ketidaktelitian penyalin sehingga beberapa huruf hilang (haplografi). Nabilah Lubis, Naskah, Teks dan Metode Penelitian Filologi ..., hal. 30.

${ }^{10}$ Baroroh Baried, yang dikutip Nabilah Lubis, ibid., hal. 24.

Jurnal Ilmiah Al QALAM, Vol. 11, No. 23, Januari-Juni 2017 
penciptanya/penulisnya,

3) Mengungkapkan nilai-nilai budaya lama sebagai alternatif pengembangan kebudayaan.

b. Tujuan Khusus

1) Menyunting sebuah teks yang dipandang dekat dengan teks aslinya,

2) Mengungkapkan sejarah terjadinya teks dan sejarah perkembangannya,

3) Mengungkapkan persepsi pembaca pada setiap kurun/zaman penerimaannya.

Setiap naskah mengandung informasi yang sangat berharga.Apabila naskah diteliti isinya dengan menggunakan pendekatan filologi, maka hasilnya dapat digunakan oleh cabangcabang ilmu lain, seperti sejarah, hukum (terutama hukum adat), perkembangan agama, kebahasaan, kebudayaan, dan sangat bermanfaat dipublikasikan untuk umum.Hasil penelitian naskah berarti merupakan sumbangan pikiran yang sangat berarti terlebihlebih dalam rangka memperkenalkan buah pikiran para pendahulu, sehingga dapat dikenal dan diketahui oleh generasi-generasi berikutnya. Karena menurut Haryati Soebadio, filologi adalah pekerja kasar yang menyiapkan suatu naskah untuk bisa dipergunakan oleh orang lain dalam berbagai disiplin ilmu. ${ }^{11}$

4. Ilmu Bantu Filologi

Dalam penelitian filologi, para filolog dituntut untuk memanfaatkan ilmu pengetahuan yang diharapkan dapat

\footnotetext{
${ }^{11}$ Haryati Soebadio, yang dikutip Nabilah Lubis, Naskah, Teks dan Metode Penelitian Filologi, ..., hal. 25.
}

Jurnal Ilmiah Al QALAM, Vol. 11, No. 23, Januari-Juni 2017 
mengungkapkan dan menjelaskan ilmu-ilmu yang terkandung dalam teks.Karena filologi dengan ilmu yang lainnya memiliki hubungan yang sangat erat, yaitu hubungan timbal balik atau saling membutuhkan.

Filologi memerlukan ilmu-ilmu bantu yang erat hubungannya dengan bahasa, masyarakat, budaya yang melahirkan naskah dan ilmu sastra untuk mengungkapkan nilai-nilai sastra yang terkandung didalamnya. Diantara ilmu tersebut:

a. Paleografi

Paleografi adalah ilmu yang mempelajari tentang pelbagai tulisan kuno di atas batu, logam atau bahan lain. ${ }^{12}$ Paleografi mempuyai tujuan utama menjabarkan tulisan kuno karena beberapa tulisan kuno sangat sulit dibaca.Disamping itu, juga bertujuan menempatkan berbagai peninggalan tertulis dalam rangka perkembangan umum sebuah tulisan sehingga dapat ditentukan waktu dan tempat setiap bentuk tulisan dari aksara yang digunakan.Karena biasanya karya sastra tidak menyebutkan kapan dan dimana suatu karya di tulis, serta siapa pengarangnya. ${ }^{13}$ Semula paleografi digunakan untuk membaca tulisan kuno yang terdapat dalam prasasti, namun pada saat sekarang juga digunakan untuk membaca tulisan kuno yang ada dalam naskah.

b. Linguistik

Linguistik memang sangat mengutamakan bahasa tulis pada awalnya, tetapi dalam perkembangannya linguistik lebih

\footnotetext{
${ }^{12}$ Nabilah Lubis, Naskah, Teks dan Metode Penelitian Filologi, ..., hal. 31.

${ }^{13}$ Nabilah Lubis, Naskah, Teks dan Metode Penelitian Filologi,..., hal. 31.
}

Jurnal Ilmiah Al QALAM, Vol. 11, No. 23, Januari-Juni 2017 
mengutamakan bahasa lisan, bahasa yang dipakai sehari-hari. Ada beberapa cabang linguistik yang dipandang dapat membantu filologi, yaitu:

1) Etimologi, yaitu ilmu yang mempelajari asal-usul dan sejarah kata. ${ }^{14}$ Hal ini didasari karena bahasa-bahasa naskah banyak yang mengandung kata serapan dari bahasa lain, yang dalam perkembangan sejarahnya perubahan bentuk dan kadang-kadang juga perubahan arti. Ilmu ini diharapkan dapat mengungkap sejarah kosakata dengan melakukan penelitian penggunaan kata dari waktu ke waktu secara diakronis. Hasil penggunaan konsep kata dari penelitian tersebut secara sinkronis dapat ditentukan masa penulisan teks. Disamping itu, penelitian secara etimologis juga dapat digunakan untuk memahami perubahan konsep makna bahasa sebagai salah satu unsur kebudayaan yang secara kultural dan struktural terkait dengan unsur-unsur kebudayaan lainnya. Kata "ulama" misalnya, kata ini pada abad keenam belas digunakan dengan konsep makna "cerdik pandai", sedangkan pada abad kesembilan belas telah digunakan dengan konsep makna "ahli dalam bidang agama”. Penggunaan konsep makna pertama justru muncul dalam masyarakat yang mayoritas agamanya adalah Islam atau masyarakat yang kebudayaannya diwarnai oleh sistem religi berdasarkan agama Islam, sedangkan penggunaan konsep makna yang kedua

\footnotetext{
${ }^{14}$ Nabilah Lubis, Naskah, Teks dan Metode Penelitian Filologi, .., hal. 55.
}

Jurnal Ilmiah Al QALAM, Vol. 11, No. 23, Januari-Juni 2017 
muncul pada masyarakat yang sekuler yang mencoba memisahkan antara kehidupan beragama dengan kebudayaan profan. ${ }^{15}$

2) Etnolinguistik, ialah cabang lingusitik yang menyelidiki hubungan antara bahasa dan masyarakat pedesaan atau masyarakat yang belum mempunyai tulisan; atau cabang liguistik yang menyelidiki hubungan bahasa dan sikap bahasawan terhadap bahasa. Ilmu ini sangat berguna untuk penelitian teks lisan baik yang bergenre mite, legenda, dan dongeng. Disamping itu, juga sangat berguna untuk menentukan varian bahasa Melayu rendah. $^{16}$

3) Sosiolinguistik, adalah ilmu yang mempelajari hubungan dan saling mempengaruhi antara perubahan bahasa dan perilaku masyarakat. ${ }^{17}$ Ilmu ini diharapkan dapat membantu mengungkapkan keadaan sosio budaya yang terkandung dalam naskah.

4) Stilistik (stylistika), yaitu cabang linguistik yang menyelidiki bahasa sastra, khususnya gaya bahasa dan diharapkan dapat membantu filologi dalam menemukan teks asli atau paling mendekati aslinya serta penentuan umur. $^{18}$

c. Bahasa yang Mempengaruhi Teks

${ }^{15}$ Ibnu Santosa, Ilmu Bantu Filologi, http://ibnusantosa.blogspot.com, di akses 26 Desember 2008.

${ }^{16}$ Sebagaimana dikutip oleh Ibnu Santosa dalam Kamus Linguistik, Ilmu Bantu Filologi, http://ibnusantosa.blogspot.comdi akses 26 Desember 2008.

${ }^{17}$ Nabilah Lubis, Naskah, Teks dan Metode Penelitian Filologi, ...., hal. 55.

${ }^{18}$ Nabilah Lubis, Naskah, Teks dan Metode Penelitian Filologi, .., hal. 56.

Jurnal Ilmiah Al QALAM, Vol. 11, No. 23, Januari-Juni 2017 
Bahasa yang mempengaruhi bahasa naskah-naskah yang ada khususnya naskah-naskah asal nusantara, seperti:

1) Bahasa sansekerta, bahasa yang digunakan oleh bangsabangsa yang tinggal di wilayah India dan telah digunakan secara tekstual setidak-tidaknya sejak abad keempat Masehi. Fenomena tersebut didasarkan atas ditemukannya prasasti berbahasa Sansekerta dengan menggunakan huruf Palawa. Aksara ini digunakan oleh raja-raja dinasti Palawa di India Selatan. Bahasa ini juga digunakan dalam teks Hindu yang tersebar luas di wilayah Asia, Asia Timur, dan Asia Tenggara. ${ }^{19}$ Dalam naskah Jawa kuno tampak jelas pengaruh bahasa ini, seperti penyerapan kosakata dan fase. Disamping itu, akan terdapat banyak cuplikan yang kadang-kadang tanpa terjemahan. Pengaruh semacam ini tampak jelas dalam Kakawin Rasmayana, Uttarakanda, Sang Hyang Kamahayanikam. $^{20}$

2) Bahasa Arab adalah bahasa yang digunakan dalam alQur'an dan hadis Nabi Muhammad saw sebagai sumber hukum agama Islam, serta digunakan dalam upacaraupacara ritual peribadatan, seperti shalat, berdoa, haji, dan upacara ritual lainnya. Sebagai bahasa sumber hukum agama Islam dan bahasa upacara ritual peribadatan, setiap muslim wajib hukumnya memahami semua aturan dan konsep-konsep dasar yang tercantum

\footnotetext{
${ }^{19}$ Ibnu Santosa, Ilmu Bantu Filologi, http://ibnusantosa.blogspot.comdi akses 26 Desember 2008.

${ }^{20}$ Nabilah Lubis, Naskah, Teks dan Metode Penelitian Filologi, .., hal. 55.
}

Jurnal Ilmiah Al QALAM, Vol. 11, No. 23, Januari-Juni 2017 
di dalamnya, dan juga semua ucapan-ucapan, doa, dan ungkapan-ungkapan yang digunakan dalam melakukan peribadatan atau upacara ritual supaya memahami betul apa yang telah dilakukan sehingga dapat mencapai tingkatan khusuk. Untuk bisa memahami kedua sumber hukum dan ungkapan-ungkapan tersebut maka syarat utamanya ialah memahami bahasanya, yaitu bahasa Arab. Dalam pondok pesantren, bahasa Arab sering disebut sebagai ilmu alat, yaitu alat untuk memahami agama. $^{21}$ Penggunaan bahasa Arab juga diperlukan terutama untuk mengkaji naskah-naskah pengaruh Islam, khususnya yang berisi ajaran tasawuf atau suluk.

3) Pengetahuan bahasa-bahasa daerah nusantara, disamping bahasa-bahasa asing yang besar pengaruhnya seperti yang disebut di atas, maka untuk penggarapan naskahnaskah nusantara dibutuhkan pengetahuan tentang bahasa daerah yang erat kaitannya dengan bahasa naskah. Pengetahuan ini diperlukan jika ingin menerjemahkan naskah dari salah satu bahasa daerah ke dalam bahasa Indonesia, sebagaimana dari kegiatan ahli filologi. $^{22}$

\section{d. Ilmu Sastra}

Sebagaimana diketahui bahwa sebagian besar teks variabel yang dijadikan objek penelitian filologi adalah berupa teks sastra.Keadaan ini menuntut filolog untuk menguasai ilmu

${ }^{21}$ Ibnu Santosa, Ilmu Bantu Filologi, http://ibnusantosa.blogspot.comdi akses 26 Desember 2008.

${ }^{22}$ Nabilah Lubis, Naskah, Teks dan Metode Penelitian Filologi, .., hal. 55.

Jurnal Ilmiah Al QALAM, Vol. 11, No. 23, Januari-Juni 2017 
sastra bila ingin mengungkap makna teks yang juga dapat dilanjutkan untuk memahami kebudayaan yang tersirat dalamnya.Oleh karena itu, penguasaan ilmu sastra merupakan syarat dasar yang harus dimiliki oleh seorang filolog.

Sebuah karya sastra mempunyai unsur-unsur, antara lain, alur, latar, perwatakan, pusat pengisahan dan gaya, yang kesemuanya terjalin menjadi satu struktur atau satu kesatuan organis. Pembahasan mengenai unsur-unsur ini termasuk pendekatan intrinsik, yaitu suatu pendekatan yang berusaha menafsirkan, menganalisis karya sastra dengan teknik dan metode yang diarahkan kepada dan berasal dari karya sastra itu sendiri. ${ }^{23}$ Sampai sekarang para ahli filologi lebih banyak melakukan pendekatan intrinsik, meskipun telah dimulai penerapan pendekatan intrinsik, misalnya pendekatan struktural yang dilakukan oleh Sulastin Sutrisno terhadap naskah hikayat Hang Tuah, pada $1979 .{ }^{24}$ Baru-baru ini terdapat pula pendekatan reseptik, yaitu suatu pendekatan yang menitikberatkan kepada tanggapan pembaca, tanggapan sekelompok masyarakat bukan peorangan. ${ }^{25}$

Sesuai dengan tujuan umum filologi, yaitu memahami budaya bangsa melalui karya sastranya baik tulis maupun lisan maka ilmu sastra secara teknis diperlukan untuk mengungkap budaya melalui karya sastra tersebut. Yang dimaksud ilmu

${ }^{23}$ Sulastin Sutrisno, yang dikutip Nabilah Lubis, Naskah, Teks dan Metode Penelitian Filologi, .., hal. 57.

${ }^{24}$ Nabilah Lubis, Naskah, Teks dan Metode Penelitian Filologi, .., hal. 57.

${ }^{25}$ Teeuw, yang dikutip Nabilah Lubis, Naskah, Teks dan Metode Penelitian Filologi, .., hal. 57.

Jurnal Ilmiah Al QALAM, Vol. 11, No. 23, Januari-Juni 2017 
sastra ialah ilmu yang membahas permasalahan yang berkaitan dengan keberadaan teks sastra baik yang berkaitan dengan unsur yang terdapat dalam teks sastra tersebut maupun unsur-unsur yang berada di luarnya dengan tujuan untuk memahami fenomena sastra. Secara teoritis, ilmu sastra yang digunakan untuk meneliti sastra menurut Abram berobjek pada 1) teks sastra, 2) pengarang sastra, 3) ,dan 4) penikmat/pembaca sastra. $^{26}$

\section{Cara Kerja Penelitian Filologi}

Untuk mendapatkan hasil penelitian yang baik, ada beberapa langkah yang harus ditempuh untuk mengawali proses penelitian filologi adalah sebagai berikut:

a. Interventaris Naskah

Langkah pertama yang harus ditempuh oleh penyunting, setelah menentukan pilihannya terhadap naskah yang ingin disunting ialah menginventarisasikan sejumlah naskah dengan judul yang sama dimanapun berada, di dalam maupun luar negeri. Naskah dapat dicari melalui katalogus perpustakaanperpustakaan besar yang menyimpan koleksi naskah, museummuseum, universitas-universitas, masjid, gereja dan lain sebagainya.Ia dapat menghubungi tempat penyimpanan naskah itu dan meminta kopinya serta semua informasi tentang naskah itu. Misalnya, menanyakan kapan naskah itu mulai masuk koleksi perpustakaan ini, apakah asalnya dari pembelian atau

\footnotetext{
${ }^{26}$ Ibnu Santosa, Ilmu Bantu Filologi, http://ibnusantosa.blogspot.comdi akses 26 Desember 2008.
}

Jurnal Ilmiah Al QALAM, Vol. 11, No. 23, Januari-Juni 2017 
hadiah, berasal dari mana dan sebagainya. ${ }^{27}$

Naskah-naskah yang diperlukan dapat diperoleh dengan memesan didaftar untuk mengetahui jumlah naskah dan dimana naskah itu disimpan, serta penjelasan mengenai nomor naskah, ukuran naskah, tulisan naskah, tempat dan tanggal penyalinan naskah.Keterangan-keterangan ini dapat dilihat dalam katalogus.Selain itu, harus diketahui bahwa semua usaha telah dilakukan untuk mencari varian sebelum mulai mengadakan penelitian, tempat semua varian atau salinan dari naskah itu berada.Meskipun demikian masih banyak naskah yang terdapat dalam bentuk naskah tunggal (Codex Unicus) ${ }^{28}$

\section{b. Deskripsi Naskah}

Langkah kedua, setelah selesai menyusun daftar naskah yang hendak kita teliti, dan naskah pun telah tersedia untuk dibaca, barulah kita membuat uraian atau deskripsi tiap-tiap naskah secara terperinci. Dalam uraian itu, disamping apa yang telah disebutkan dalam daftar naskah, juga dijelaskan keadaan naskah, kertas, watermark kalau ada, catatan lain mengenai isi naskah, serta pokok-pokok isi naskah itu. Hal ini penting sekali untuk mengetahui keadaan naskah, dan sejauh mana isi naskah itu.Penelitian ini sangat membantu kita untuk memilih naskah mana yang paling baik digunakan untuk perbandingan naskah itu. $^{29}$

Informasi seperti ini sangat diperlukan dan dapat

${ }^{27}$ Nabilah Lubis, Naskah, Teks dan Metode Penelitian Filologi, .., hal. 64.

${ }^{28}$ Nabilah Lubis, Naskah, Teks dan Metode Penelitian Filologi, .., hal. 66.

${ }^{29}$ Edwar Djamaris, Filologi dan Cara Kerja Penelitian Filologi, https://www.scribd.com/, di akses 26 Desember 2012.

Jurnal Ilmiah Al QALAM, Vol. 11, No. 23, Januari-Juni 2017 
membantu menentukan naskah mana yang akan dipilih untuk menjadi dasar edisi. Misalnya, ada naskah yang kertasnya rusak, sedangkan yang lain keadaannya lebih baik. Kelengkapan informasi yang terdapat dalam bagian akhir naskah seperti keterangan nama penyalin dan tempat penyalinannya, serta tanggalnya. Keterangan semacam ini dinamakan "kolofon". Informasi yang perlu dicatat, antara lain halaman depan kurang atau halaman terakhir hilang sebagian, sedangkan pada naskah yang lain halaman itu ada. Bila terdapat catatan-catatan pinggir atau catatan dengan tulisan lain atau warna tinta lain, semua keterangan itu penting dicatat. ${ }^{30}$

c. Pengelompokan dan Perbandingan Teks

Untuk mengadakan pengelompokan naskah, proses awal yang harus dilakukan oleh seorang editor atau filolog ialah mengadakan penelitian yang cukup mendalam sehingga akhirnya dapat diketahui hubungan antar varian, perbedaan, persamaan dan hubungan kekerabatan antara berbagai naskahyang ada. Dalam pengelompokan naskah dapat dikerjakan dengan mengadakan kritik teks, yaitu kritik dalam (internal) dan kritik luar (external) atau yang biasanya disebut kritik.Kritik eksternal dapat membantu untuk mengetahui keabsahan naskah, jenis tulisan, kualitas kertas, latar belakang penulis, mengenai waktu dan tempat penulisannya (zaman naskah).Adapun kritik internal menitikberatkan pembahasan pada isi naskah, tujuan penulis sebagaimana yang dipahami dari

${ }^{30}$ Nabilah Lubis, Naskah, Teks dan Metode Penelitian Filologi, .., hal. 67.

Jurnal Ilmiah Al QALAM, Vol. 11, No. 23, Januari-Juni 2017 
teks dan informasi yang mendukung keabsahan teks. ${ }^{31}$

Para ahli filologi menyimpulkan bahwa ada beberapa cara yang menjadikan penyalin menyimpan dari teks yang disalin, yaitu sebagai berikut:

1) Menyalin dengan membetulkan;

2) Menyalin dengan menggunakan bahasa sendiri;

3) Menyalin dengan menambah unsur atau bagian cerita baru, karena adanya pengaruh asing; dan,

4) Menyalin cerita dari cerita lisan atau sumber yang berbeda.

Hal-hal inilah yang menyebabkan perlunya naskah itu diperbandingkan.Sudah menjadi ciri sastra lama, bahwa pengarang atau penyalin cerita bebas menambah, mengubah atau memperbaiki cerita yang diperolehnya.Meskipun demikian, tentu ada batas-batasnya juga, sepanjang isi atau pokok ceritanya tidak berubah, karena mengubah suatu tradisi tabu bagi masyarakat lama.Masyarakat lama menganggap naskah itu sebagai warisan atau pusaka yang tinggi nilainya.Hal inilah yang memberi jaminan pada kita, bahwa isinya dapat dipercayai, betul-betul hidup dalam masyarakat sesuai dengan kepercayaannya dan tidak dikarang sesuka penulisnya.

Perbandingan naskah itu dapat meliputi: ${ }^{32}$

1) Perbandingan kata demi kata, untuk membetulkan katakata yang tidak terbaca atau salah;

\footnotetext{
${ }^{31}$ Nabilah Lubis, Naskah, Teks dan Metode Penelitian Filologi,.., hal. 70.

${ }^{32}$ Edwar Djamaris, Filologi dan Cara Kerja Penelitian Filologi, https://www.scribd.com/, di akses 26 Desember 2012.
}

Jurnal Ilmiah Al QALAM, Vol. 11, No. 23, Januari-Juni 2017 
2) Perbandingan susunan kalimat atau gaya bahasa, untuk mengelompokkan cerita dalam beberapa versi dan untuk mendapatkan cerita yang bahasanya lancar dan jelas; dan

3) Perbandingan isi cerita, untuk mendapatkan naskah yang isinya lengkap dan tidak menyimpang dan untuk mengetahui adanya unsur baru dalam naskah itu.

Hal ini perlu dilakukan untuk mendapatkan cerita yang bebas dari kesalahan; isi cerita tidak diinterpretasikan secara salah; penggolongan cerita sesuai dengan penyajiannya; dan untuk menentukan silsilah naskah itu.

Setelah selesai melakukan perbandingan seperti yang disebutkan diatas, barulah peneliti memilih salah satu naskah yang telah diperiksa dan diperbandingkan dijadikan sebagai landasan edisi. Disini diberikan kriteria yang dapat membantu dalam menentukan suatu naskah: ${ }^{33}$

1) Isinya lengkap dan tidak menyimpang dari kebanyakan isi naskah-naskah yang lain;

2) Tulisannya jelas dan mudah dibaca;

3) Keadaan naskah baik dan utuh;

4) Sesuai dengan sumber dan fakta;

5) Bahasanya lancar dan mudah dipahami;

6) Umur naskah lebih tua (meskipun tidak harus tua);

7) Menggambarkan apa yang diinginkan oleh pengarangnya.

d. Transliterasi/Transkripsi

${ }^{33}$ Nabilah Lubis, Naskah, Teks dan Metode Penelitian Filologi,..., hal. 72.

Jurnal Ilmiah Al QALAM, Vol. 11, No. 23, Januari-Juni 2017 
Transliterasi ialah penggantian huruf atau pengalihan huruf demi huruf dari satu abjad ke abjad yang lain. Misalnya huruf Arab-Melayu ke huruf latin. Atau perubahan teks dari satu ejaan ke ejaan lain. Misalnya, naskah-naskah yang tertulis dengan huruf Latin dengan memakai ejaan lama diubah ke dalam ejaan yang berlaku sekarang (EYD). ${ }^{34}$

Semua itu menjadi tugas filolog untuk menjelaskannya, agar tidak terdapat lagi kekeliruan atau salah penafsiran bahasa.Seorang filolog hendaklah sekurang-kurangnya mampu menyajikan bahan transliterasi atau transkripsi itu selengkapnya dan sebaik mungkin, sehingga mudah dibaca dan dipahami.

e. Terjemahan

Salah satu cara untuk menerbitkan naskah ialah melalui terjemahan teks. Seseorang bisa dikatakan penerjemah yang baik apabila orang tersebut mampu melihat alam sekitarnya dan memperhatikan hasil tulisan dan pemikiran yang ada, lalu menuangkannya ke dalam kalimat-kalimat yang tepat dan indah. Dengan kata lain, terjemahan yang baik ialah terjemahan yang mampu melukiskan apa yang ingin dikatakan oleh teks yang diterjemahkan ke dalam kalimat yang indah dan mampu mengekspresikan substansi teks sebagaimana bahasa aslinya. ${ }^{35}$ Di bawah ini dikemukakan beberapa cara untuk menerjemahkan teks, antara lain sebagai berikut:

1) Terjemahan harfiah, ialah menerjemahkan dengan menurut teks sedapat mungkin, meliputi kata demi

${ }^{34}$ Nabilah Lubis, Naskah, Teks dan Metode Penelitian Filologi,..., hal. 73.

${ }^{35}$ Al-Sulub As-Sahih Fit-Tarjamah, yang dikutip Nabilah Lubis, Naskah, Teks dan Metode Penelitian Filologi, .., hal. 75.

Jurnal Ilmiah Al QALAM, Vol. 11, No. 23, Januari-Juni 2017 
kata. ${ }^{36}$ Metode ini sangat terikat dengan teks dan urutan kata-katanya dengan tujuan menyampaikan arti teks secara tepat dan jujur tetapi seringkali hasilnya tidak memuaskan karena sering tidak terdapat arti yang persis dalam bahasa yang diterjemahkan.

2) Terjemahan agak bebas, ialah seorang penerjemah diberi kebebasan dalam proses penerjemahannya, namun kebebasan itu masih dalam batas wajar. ${ }^{37}$ Dalam artian menerjemahkan ide tulisan tidak terlalu terikat dengan susunan kata demi kata. Karena itu, penerjemah harus menguasai ke dua bahasa tersebut, baik bahasa teks maupun bahasa yang diterjemahkan ke dalamnya.

3) Terjemahan yang sangat bebas, yakni penerjemah bebas melakukan perubahan, baik menghilangkan bagian, menambah atau meringkas teks. Cara ini tidak dapat digunakan dalam menangani teks klasik yang memerlukan tingkat kejujuran dan ketelitian yang tinggi. Kesimpulan para ahli filolog bahwa cara yang kedualah yang paling sesuai untuk menerjemahkan teks klasik. ${ }^{38}$

Seorang filolog harus menjaga secara utuh dan memahami secara intens kandungan isi teks, lalu menyampaikannya harus memelihara bentuk yang diinginkan oleh pengarangnya. Dalam artian bahwa penerjemah bukanlah sekedar memindahkan arti kalimat, melainkan juga ia harus menjiwai teks sebagaimana pengarang menjiwainya. Sebab itu,

\footnotetext{
${ }^{36}$ Nabilah Lubis, Naskah, Teks dan Metode Penelitian Filologi, .., hal. 75.

${ }^{37}$ Nabilah Lubis, Naskah, Teks dan Metode Penelitian Filologi,.., hal. 75.

${ }^{38}$ Nabilah Lubis, Naskah, Teks dan Metode Penelitian Filologi, .., hal. 76.
}

Jurnal Ilmiah Al QALAM, Vol. 11, No. 23, Januari-Juni 2017 
teks harus dibaca dengan teliti dan penuh penghayatan terhadap berbagai istilah dan peristiwa yang diutarakan dalam teks.

6. Metode-Metode Penelitian Filologi

Metode sebagaimana dipahami adalah cara atau sistem kerja. Metodologi dapat pula dikatakan sebagai pengetahuan tentang apa saja yang merupakan cara untuk menerangkan atau meramalkan variabel konsep maupun definisi konsep yang bersangkutan dan mencari konsep tersebut secara empiris.

Jadi, metode filologi ialah pengetahuan tentang cara, teknik, atau instrumen yang dilakukan dalam penelitian filologi. ${ }^{39}$ Metode-metode tersebut, yaitu:

a. Metode intuitif. Dalam konteks sejarah suatu teks, besar kemungkinan mengalami penyalinan yang berulang kali dan hal itu menyebabkan terjadinya beberapa naskah yang beraneka ragam. ${ }^{40}$ Naskah disalin ulang, dengan membetulkan tempat-tempat yang tidak jelas berdasarkan naskah lain dengan pertimbangan akal sehat, selera baik dan pengetahuan luas dibidang bahasa maupun disiplin ilmu yang menjadi pokok bahasan naskah tersebut. Metode ini bertahan sampai abad ke-19, sebelum munculnya metode objektif. $^{41}$

b. Metode objektif/stema, ialah cara menentukan naskah dengan melakukan rekonstruksi naskah, yakni

\footnotetext{
${ }^{39}$ Tommy Christomy, yang dikutip Nabilah Lubis, Naskah, Teks dan Metode Penelitian Filologi, .., hal. 64.

${ }^{40}$ Nabilah Lubis, Naskah, Teks dan Metode Penelitian Filologi, .., hal. 77.

${ }^{41}$ Russel Jones, yang dikutip Nabilah Lubis, Naskah, Teks dan Metode Penelitian Filologi, ....., hal. 77.
} 
memperbandingkan naskah yang bervariasi untuk mendapatkan naskah yang dianggap paling unggul. ${ }^{42}$ Metode ini bertujuan mendekati teks asli melalui data-data naskah dengan memakai perbandingan teks. Teorinya menurut West, bahwa naskah disalin satu demi satu kesalahan yang pernah terjadi dalam naskah berikutnya dalam tradisi, akan terus diturunkan ke naskah berikutnya (turun-temurun). Metode ini dikembangkan di Eropa pada tahun 1930-an oleh "Lachmann". Kesalahan-kesalahan yang terdapat dalam proses penyalinan dari satu teks ke teks yang lain dapat dipakai untuk menunjukkan perbedaan dan kesamaan diantara naskah. ${ }^{43}$ Dalam praktiknya metode ini tidak terbebas dari berbagai masalah. ${ }^{44}$

c. Metode gabungan. Metode ini dipakai apabila nilai naskah menurut dugaan filolog semuanya hampir sama. Perbedaan antara naskah tidak terlalu besar. Pada umumnya naskah yang terpilih adalah yang mempunyai bacaan mayoritas atas dasar perkiraan bahwa jumlah naskah itu merupakan saksi bacaan yang benar. Dengan metode ini, teks yang disunting merupakan teks baru dan gabungan bacaan dari semua naskah yang ada. ${ }^{45}$

\footnotetext{
${ }^{42}$ Kun Zachrun Istanti, "Studi Manuskrip dan Muatannya” pada Seminar Regional Studi Manuskrif Dalan Khazanah Qur'anic and Hadith Studiesdi UIN Sunan Kalijaga Yogyakarta, 16 Desember 2008, hal. 4.

${ }^{43}$ Martin L. West, yang dikutip Nabilah Lubis, Naskah, Teks dan Metode Penelitian Filologi, ., hal. 77.

${ }^{44}$ Masalah tersebut antara lain, metode ini berdasarkan pada pilihan antara bacaan yang benar dan salah. Dalam kenyataannya sulit menentukan pilihan itu. Lebih lanjut lihat Nabilah Lubis, Naskah, Teks dan Metode Penelitian Filologi,..., hal. 82.

${ }^{45}$ Nabilah Lubis, Naskah, Teks dan Metode Penelitian Filologi..., hal. 84.
}

Jurnal Ilmiah Al QALAM, Vol. 11, No. 23, Januari-Juni 2017 
d. Metode landasan. Metode ini diterapkan apabila menurut tafsiran ada beberapa naskah unggul kualitasnya dibanding dengan naskah-naskah yang lain. Hal ini diketahui bila diadakan penelitian yang cermat terhadap bahasa, kesastraan, sejarah dan segala hal tentang teks, sehingga dapat dikatakan bahwa teks A misalnya, lebih unggul dibanding C, D, atau E. Karena itu, teks yang dinyatakan memiliki bacaan yang paling baik itu, dijadikan dasar untuk edisi atau penyuntingan naskah. Metode ini disebut juga dengan "metode induk". ${ }^{46}$ Pemilihan dan penentuan naskah yang mengandung bacaan yang baik dilakukan berdasarkan berbagai kriteria, antara lain, usia naskah. Bila terdapat naskah tertua, perlu mendapat perhatian perhitungan dan diprioritaskan, akan tetapi tidak harus selalu naskah tertua yang dipilih. Perlu juga diperhitungkan aspek-aspek penampilan dari berbagai segi baik bahasa, kejelasannya (tidak terdapat kerusakan yang mengganggu bacaannya), dan kelengkapan informasi yang mengandungnya, seperti keterangan nama pengarang, tempat dan tanggal penulisannya. $^{47}$

e. Metode analisis struktur. Metode ini terhadap sebuah karya bertujuan untuk memaparkan secermat mungkin keterkaitan semua unsur-unsur dan aspek karya sastra yang bersamasama menghasilkan makna yang menyeluruh. ${ }^{48}$ Menurut A. Teeuw, bahwa tidak ada sebuah reseppun untuk analisis

\footnotetext{
${ }^{46}$ Nabilah Lubis, Naskah, Teks dan Metode Penelitian Filologi,.., hal. 85.

${ }^{47}$ Nabilah Lubis, Naskah, Teks dan Metode Penelitian Filologi,.., hal. 86.

${ }^{48}$ Nabilah Lubis, Naskah, Teks dan Metode Penelitian Filologi,.., hal. 87.
}

Jurnal Ilmiah Al QALAM, Vol. 11, No. 23, Januari-Juni 2017 
struktural semacam ini yang tinggal diterapkan saja. Setiap karya memerlukan metode analisis yang sesuai dengan sifat dan strukturnya. ${ }^{49}$

f. Metode penelitian naskah tunggal. Apabila peneliti hanya menemukan satu naskah untuk teks yang ingin diedit, maka hanya terdapat dua pilihan, yaitu mengadakan: $:^{50}$

1) Edisi diplomatik, ialah suatu cara mereproduksi teks sebagaimana adanya tanpa ada perbaikan atau perubahan dari editor. Metode yang paling sesuai dengan tujuan ini adalah naskah direproduksi secara fotografis. Hal ini penting, jika peneliti ingin penampilkan teks yang diperoleh persis sebagaimana adanya. Tetapi bagi pembaca modern, metode ini tidak memberikan informasi yang membantu dalam upaya memahami teks tersebut.

2) Edisi standar, yaitu suatu usaha perbaikan dan meluruskan teks sehingga terhindar dari berbagai kesalahan dan penyimpangan-penyimpangan yang timbul ketika proses penulisan. Tujuannya ialah untuk menghasilkan suatu edisi yang barudan sesuai dengan kemajuan dan perkembangan masyarakat. Sungguhpun demikian yang harus diingat bahwa editor harus bertanggungjawab terhadap semua perbaikan atau penafsiran yang diadakan serta harus menyebutkan sumbernya.

\footnotetext{
${ }^{49}$ Teeuw, yang dikutip Nabilah Lubis, Naskah, Teks dan Metode Penelitian Filologi, ... hal. 87.

${ }^{50}$ Nabilah Lubis, Naskah, Teks dan Metode Penelitian Filologi,.., hal. 88.
}

Jurnal Ilmiah Al QALAM, Vol. 11, No. 23, Januari-Juni 2017 


\section{Penutup}

Masih banyak teks-teks atau kitab-kitab keagamaan Islam yang belum terpelihara dengan cermat, padahal itu merupakan peninggalan masa lalu yang sangat berharga, karena dari teks atau kitab tersebut kita bisa mengetahui kondisi pengarang, masyarakat serta lingkungan dimana teks atau kitab tersebut lahir. Filologi sebagai salah satu pendekatan untuk mengkaji serta memahami teks, sehingga dihasilkan teks yang terpisah dari kesalahan-kesalahan dan juga mengadakan kritik terhadap teks, dan tujuan kritik teks ialah menghasilkan suatu teks yang paling mendekati aslinya. Teks yang sudah dibersihkan dari kesalahan-kesalahan dan telah tersusun kembali seperti semula merupakan teks yang dapat dipertanggungjawabkan sebagai sumber untuk kepentingan berbagai penelitian dalam bidang-bidang ilmu lain.

Yang perlu diperhatikan bagi orang yang ingin melakukan penelitian teks yang berhubungan dengan kitab keagamaan adalah kemampuan untuk memisahkan antara sikap yang tepat dan yang mesti diambil oleh orang peneliti "beriman" kepada kitab sucinya dan keharusan untuk menerapkan metode (teori) penelitian. Karena salah satu keharusan dasar dari sebuah kajian ilmiah adalah memahami objek sebaik mungkin.

Jurnal Ilmiah Al QALAM, Vol. 11, No. 23, Januari-Juni 2017 


\section{DAFTAR PUSTAKA}

Edwar Djamaris, Filologi dan Cara Kerja Penelitian Filologi https://www.scribd.com/, di akses 26 Desember 2012.

Ibnu Santosa, Ilmu Bantu Filologi, http://ibnusantosa.blogspot.comdi akses 26 Desember 2008.

Istanti, Kun Zachrun.2008. "Studi Manuskrip dan Muatannya" pada Seminar Regional Studi Manuskrif Dalan Khazanah Qur'anic and Hadith Studiesdi UIN Sunan Kalijaga Yogyakarta, 16 Desember 2008.

Istadiyantha, Edisi Teks dan Ruang Lingkup Pengembangan Penelitian Filologi, https://www.scribd.com/, di akses 26 Desember 2012.

Kamil, Habib. 2008.“Tahkik Al-Kutub: Menyoal Peran Perguruan Tinggi Dalam Menyelamatkan Orisinalitas Intelektual Bangsa" pada Seminar Regional Studi Manuskrif Dalan Khazanah Qur'anic and Hadith Studiesdi UIN Sunan Kalijaga Yogyakarta, 16 Desember 2008.

Lubis, Nabilah. 1996.Naskah, Teks dan Metode Penelitian Filologi. Jakarta: Forum Kajian Bahasa dan Sastra Arab Fak. Adab IAIN Syarif hidayatullah.

Machasin. 2006. "Penelitian Bahasa dan Sastra Dalam Kajian Keislaman" dalam Ahmad Pattiroy, (ed.) Filsafat dan Bahasa Dalam Studi Islam.Yogyakarta: Lembaga Penelitian UIN Sunan Kalijaga.

Jurnal Ilmiah Al QALAM, Vol. 11, No. 23, Januari-Juni 2017 